\title{
Animal models for the study of energy balance
}

By. M. I. GuRR, Nutrition Department, National Institute for Research in Dairying, University of Reading, Shinfield, Reading RG2 $q A T$

The most obvious outcome of the failure to regulate energy balance effectively in animals and man is obesity. To learn how obesity arises and may be prevented, we must understand how animals regulate energy balance or metabolism, but a concentration on obesity as such may focus too much research attention on the adipose tissue, a proliferation of which is the outward sign of a tendency towards positive energy balance though not necessarily the cause of it.

Rather than attempting a complete review, I shall select several current areas of research to illustrate specific points in connexion with the question: why do we need 'models'?

\section{The concept of energy balance}

An animal is said to be in energy balance when his body energy stores remain constant. His energy intake (metabolizable energy of food) then equals his energy expenditure (total heat output). Energy balance is positive if intake exceeds output; negative if output exceeds input.

$$
E_{\text {IN }}-E_{\text {OUT }}=\Delta \text { body energy }
$$

At least two terms in the equation should be measured. This is accomplished more simply and with greater accuracy over longer periods with animals than with man: a compelling reason for studying animal models to understand basic mechanisms. Changes in body energy are quite difficult to assess properly in man. Deposition of adipose tissue is associated with increases in protein and water as well as fat. Changes in carcass energy can be measured accurately in animals by direct chemical analysis, but it is surprising how frequently this is omitted. It is common for authors to refer only to weight gain as though this can fully describe a change in energy balance. Energy balance can change quite dramatically without any change in weight as illustrated by an example from our work with piglets (Gurr et al. 1980). A group of piglets was fed on a diet of low-protein content (approximately $2 \%$ of metabolizable energy) ad lib. The protein level was adjusted so that animals maintained weight. A second group was fed on a high-protein diet (27\% of $\mathrm{ME}$ ) so as to maintain the same weight. The fundamentals of this experiment were first described by Miller \& Payne (1962). At the beginning and end of the experiment, the animals were slaughtered and carcass composition measured. In low-protein pigs, there was a significant increase in carcass energy without a significant change in weight (Table 1 ) and this was accompanied by a higher proportion of carcass fat $(8-30 \%)$ and a lower proportion of body water $0029-6651 / 80 / 3933-4102$ Sor $.00(\mathcal{C} 1980$ The Nutrition Society 
Table I. Energy balance in pigs maintaining weight on different energy intakes

(Mean values with their standard errors)

\begin{tabular}{|c|c|c|c|c|c|c|c|}
\hline \multirow[b]{2}{*}{ Group } & \multicolumn{2}{|c|}{ Body-weight } & \multicolumn{2}{|c|}{ Body energy } & \multirow{2}{*}{$\begin{array}{c}\text { Metabolizable } \\
\text { energy } \\
\text { intake } \\
(\mathrm{MJ} / \mathrm{d})\end{array}$} & \multirow{2}{*}{$\begin{array}{l}\text { Calculated } \\
\text { energy } \\
\text { expenditure } † \\
(\mathrm{MJ} / \mathrm{d})\end{array}$} & \multirow{2}{*}{$\begin{array}{c}\text { Heat } \\
\text { production } \ddagger \\
(\mathrm{MJ} / \mathrm{d})\end{array}$} \\
\hline & $\begin{array}{c}\text { Initial } \\
(\mathbf{k g})\end{array}$ & $\begin{array}{c}\text { Final } \\
(\mathbf{k g})\end{array}$ & $\begin{array}{l}\text { Initial } \\
\text { (MJ) }\end{array}$ & $\begin{array}{l}\text { Final } \\
\text { (MJ) }\end{array}$ & & & \\
\hline $\begin{array}{l}\text { HP-IIl } \\
\text { LP-II } \\
\text { HP-2§ } \\
\text { LP-2§ }\end{array}$ & $\begin{array}{c}6 \cdot 0 \pm 0 \cdot 5 \\
6 \cdot 0 \pm 0 \cdot 5 \\
6 \cdot 0 \\
6 \cdot 0\end{array}$ & $\begin{array}{c}7 \cdot 1 \pm 0 \cdot 2 \\
6 \cdot 6 \pm 0 \cdot 2 \\
6 \cdot 1 \\
5 \cdot 8\end{array}$ & $\begin{array}{c}38 \cdot 5 \pm 2 \cdot 0 \\
3^{8} \cdot 5 \pm 2 \cdot 0 \\
3^{8 \cdot} \cdot 5 \\
3^{8 \cdot} \cdot 5\end{array}$ & $\begin{array}{c}45 \cdot 1 \pm 2 \cdot 0 \\
82 \cdot 9 \pm 6 \cdot 9^{\circ 0} \\
34 \cdot 0 \\
45 \cdot 0\end{array}$ & $\begin{array}{c}\text { I.92 } \pm 0 . \text { I I } \\
5.42 \pm 0.42 \\
\text { I. } 34 \\
4.41\end{array}$ & $\begin{array}{c}1 \cdot 7^{6} \pm 0.18 \\
3 \cdot 71 \pm 0.06^{\circ} \\
1 \cdot 87 \\
2 \cdot 59\end{array}$ & $\begin{array}{c}1 \cdot 70 \pm 0 \cdot 05 \\
2 \cdot 21 \pm 0 \cdot 01 \cdot \\
1 \cdot 73 \\
2 \cdot 5^{8}\end{array}$ \\
\hline & & $\begin{array}{l}\text { HP, high } \\
\text { - } P<0.05 \text {, } \\
+ \text { Energy } \\
\text { † Heat pr } \\
\text { "Three a } \\
\text { §One ani }\end{array}$ & $\begin{array}{l}\text { protein; LP } \\
\bullet P<0 \text { or } \\
\text { expenditure } \\
\text { oduction de } \\
\text { nimals per } \\
\text { mal per gro }\end{array}$ & $\begin{array}{l}\text { low protein. } \\
\text { (compared } w \\
\text { calculated b) } \\
\text { termined by } \\
\text { group fed for } \\
\text { oup fed for } 5\end{array}$ & $\begin{array}{l}\text { vith } \mathrm{HP} \text { ). } \\
\text { y the balance } \\
\text { indirect calorir } \\
26 \mathrm{~d} \text {. }\end{array}$ & $\begin{array}{l}\text { method. } \\
\text { metry. }\end{array}$ & \\
\hline
\end{tabular}

$(74-54 \%)$ and protein $(15-12 \%)$. Another important point is illustrated in Table 1. Energy expenditure may be assessed as that energy that remains after subtracting excreted energy and energy deposited in the carcass from energy consumed. It may also be measured by calorimetry but the answer will not necessarily be the same. A $24 \mathrm{~h}$ heat production measurement may not be representative of energy balance over a 2-week period (LP-I in Table I) but better agreement can be obtained if the animals' heat production is measured in the chamber throughout the balance trial (HP-2, LP-2 in Table r). Change of environment and day-to-day fluctuations in expenditure no doubt contribute to these discrepancies. It should be emphasized that human calorimetry is rarely performed for more than $3^{6 \mathrm{~h}}$ at a time.

\section{Energy absorption}

Energy intake has often appeared to be the most variable component of the balance equation, and in view of the many difficulties that have attended the accurate long-term measurement of energy expenditure, perhaps it is understandable why control of energy intake has been regarded as the predominant factor in energy balance regulation. A number of metabolic controls of energy intake have been proposed (Mayer, 1953; Hervey, 1969; Mayer \& Thomas, 1967). Booth et al. (1976) have extended these proposals with the hypothesis that the signal to the neural receptors that control feeding depends on the current supply of energy for intermediary metabolism from sources such as sugars, amino acids, ketones, glycerol and lactate, and have devised computer models to predict feeding behaviour in rats and man.

One factor that controls energy supply is the rate of gastric emptying which regulates the flow of nutrients to the intestine for absorption and therefore influences the time of arrival of substrates at sites of metabolism. We chose the pig 
as an animal model to clarify basic mechanisms not easily investigated in man. Our choice was made on the grounds that the pig is omnivorous, is a natural diurnal feeder (Auffray et al. 1974), the anatomy of its gastrointestinal tract is similar to man's and it is large enough to allow surgical insertion of gut cannulas with relative ease. The degree of digestion and rate of flow of dietary components from the stomach can be assessed by means of a re-entrant cannula in the proximal duodenum fitted with an automatic sampler that interrupts flow for $5 \mathrm{~s}$ in every roo s (Low, r979). It is planned to avoid complications arising from the action of pancreatic and bile secretions by re-routing pancreatic and bile ducts to enter more distally.

In man, the best information currently available on gastric emptying can be obtained by labelling foods with gamma-emitting isotopes and detecting the emissions with a gamma-camera (Harvey et al. 1970). The intricacy and expense of the equipment will inevitably limit its use and, so far, reliable results have only been gathered for liquid foods. Surgically prepared pigs provide a ready means for studying the emptying of solid diets of all types. For example, preliminary work (Leeds et al. 1980) suggests that guar gum in diets affects post-prandial glucose and insulin profiles similarly in pig and man and that this may be related to the effect of the viscosity of the food on the rate of gastric emptying. The suggestion that the energy value of a meal is a primary factor affecting gastric emptying in non-human primates deserves further study (Chaddock et al. 1974).

\section{The concept of regulation}

Early observations that energy intake of rats remained fairly constant despite marked changes in the energy density of the diet led Adolph (1947) to the conclusion that rats 'eat for calories'. Subsequently, the rat has been regarded as a 'poor model' for obesity in man because of its outstanding ability to regulate energy balance compared with man's poor performance. Nevertheless, this apparent ability to detect energy density starts to break down as the proportion of fat in the diet becomes greater though there are large differences between strains, indicating a strong genetic influence (Schemmel \& Mickelsen, 1973; Miller, 1979). If a regulatory system can be challenged by dietary manipulation in this way, are there mechanisms tending to restore body energy to its previous level when the challenge has been removed?

Two models for inducing obesity have been found useful: intragastric feeding (Cohn \& Joseph, 1960) and 'cafeteria' feeding (Sclafani \& Springer, 1976). Table 2 illustrates the point that the physiological response to intragastric feeding is dependent on the nature of the diet fed (Gurr et al. 1978). In each experiment, animals had free access to chow diet. When given part of their normal food intake (ranging from 34 to $75 \%$ ) as 'Complan' (a nutritionally 'balanced' diet) the animals compensated by reducing voluntary food intake. However, body energy increased indicating a raised metabolic efficiency. When the animals were given fat (a nutritionally unbalanced diet) they no longer compensated by reducing voluntary food intake. Those given fats containing predominantly long-chain fatty acids 
Table 2. Energy intake, body-weight gain and metabolic efficiency after tube feeding different diets to rats

(Mean values with their standard errors)

Diet

\section{Control}

Tube fed 'complan'

Tube fed butter

Tube fed corn oil

Tube fed coconut oil

\begin{tabular}{|c|c|}
\hline \multicolumn{2}{|c|}{ Energy intake } \\
\hline $\mathrm{MJ} / 30 \mathrm{~d}$ & $\%$ of control \\
\hline $11 \cdot 34 \pm 0 \cdot 11$ & 100 \\
\hline $11.65 \pm 0.14$ & 103 \\
\hline $13.20 \pm 0.16^{\circ \cdots \bullet}$ & 116 \\
\hline $13.00 \pm 0.50^{\circ *}$ & II 5 \\
\hline $12.05 \pm 0.19^{\circ \bullet}$ & 106 \\
\hline
\end{tabular}

\section{Efficiency}

(g gained/MJ eaten)

(g)

$44 \pm 5$

$71 \pm 10^{\circ}$

$64 \pm 9$

$59 \pm 10$

$29 \pm 4 *$

$3.88 \pm 0.3^{8}$
$6.61 \pm 0.5^{8}$
$4.85 \pm 0.63$
$4.54 \pm 0.77$
$2.41 \pm 0.38^{\circ}$

'Control animals ate laboratory chow only ad lib.; at the start the mean body-weight of all groups was $430 \pm 5 \mathrm{~g}$.

\footnotetext{
$\bullet P<0.05, \cdots P<0.01, \cdots P<0.001$ (compared with control)

$\dagger>90 \%$ fat, by a tritiated water dilution method.
}

increased body energy somewhat with little increase in efficiency while those given fats containing medium-chain fatty acids decreased body energy and metabolic efficiency significantly.

In the 'cafeteria' model, animals are fed on a selection of human foods such as chocolate biscuits and potato crisps as well as having access to pelleted chow. The resulting increase in energy intake and body energy gain are strongly influenced by the origins and background of the animals (Rothwell \& Stock, 1980). Two separate colonies of Sprague-Dawley rats were compared. When they were fed on chow for $8 \mathrm{~d}$, energy balance of the two colonies was identical. When they were fed on 'cafeteria' foods, although energy intakes were similar, animals in one colony gained considerably more weight and had a lower energy expenditure than the other.

If body fat is a regulated quantity its amount should change towards a 'normal' value when the stimulus for energy gain (tube or 'cafeteria' feeding) is removed. In the experiments of Rothwell \& Stock ( 1980 ) 'recovery' of tube-fed animals was brought about by a decrease in energy intake without a change in metabolic efficiency; 'recovery' from cafeteria feeding was accompanied partly by a decreased energy intake and partly by an increased metabolic rate. In the experiments of Rolls et al. (1980) the obesity was irreversible. The differences may be accounted for by differences in the strain of rats, the time for which 'overfeeding' was continued and the variety of palatable foods offered.

The success of modern intensive livestock production has involved the development of fast growing breeds with heavy reliance on the promotion of high food intakes. This might imply that there is no significant decrease in efficiency of utilization of dietary energy at high energy intakes. There are, however, large differences between breeds, exemplified in pigs by the faster growing, fat, Gloucester Old Spot and Large White and the slower growing, lean, Pietrain 
(Lodge et al. 1978; Lister, 1980) and these are explained by differences in metabolic efficiency as well as in total food intake.

These illustrations have emphasized several important points. First, the impeccable ability of rats to regulate energy balance disappears when they are confronted with a diet familiar to Western Man; is obesity a major problem in societies that exist mainly on a single bland staple food? Second, even within strains, individuals respond in different ways to palatable diets just as individual human beings respond differently to overfeeding. Third, the metabolic changes leading to deposition or loss of body energy depend on the type of diet and the manner in which it is consumed and may involve changes in energy intake, energy expenditure or both. In assessing the relevance of these models for man it should be noted that they have paid little attention to the role of factors such as exercise or stress. The metabolic rates of rats trained to exercise are higher than those of habitually sedentary animals, and this probably has a significant effect on longterm energy balance (Gleeson et al. unpublished results). Moreover, the stress caused by placing exercise trained rats on a stationary treadmill results in a rise in oxygen consumption to levels similar to those observed in exercising, whereas the oxygen consumption of sedentary animals does not change. In general, one deliberately tries to avoid stress in experiments with laboratory and farm animals whereas in human experience stresses of many and varying types occur but are often neglected in experimentation and may account for apparent anomalies in the literature. Animal models designed to take these factors into account would be helpful but progress may depend on being able more clearly to define stress than is possible at present.

\section{The role of adipose tissue in energy balance}

Can we find, within the adipose tissue, clues to the regulation of energy balance or its failure?

Several pieces of evidence support the view that mechanisms controlling fat metabolism in adipose tissue are genetically determined. Pigs selected for leanness mobilize fatty acids more effectively in response to lipolytic hormones than do pigs selected for fatness (Standal et al. 1973). In human beings a familial pattern of obesity has been described that arises from a defect in fat mobilization (Galton et al. 1974). Loss of sensitivity to lipolytic hormones is associated with the development of the enlarged fat cells characteristic of obese rodents (York, 1979), but there is very little evidence that a primary defect in adipose tissue is an important causative factor in the aetiology of obesity.

Evidence against a primary defect in adipose tissue was presented by Ashwell et al. (1977). Fat cells in tissue transplanted from genetically obese or lean 'donor' mice into lean or obese 'hosts' acquired the size characteristic of the host animals indicating a predominant effect of tissue environment on the size of fat cells.

There are two components to the size of a fat depot: the number of fat cells and their size. Rats nourished in small litters ('overnutrition') had heavier epididymal fat pads than those nourished in large litters ('undernutrition') by the age of three 
weeks and this arose primarily by an increase in the number of fat cells (Knittle \& Hirsch, 1968). The observation that an increase in the number as well as in the size of fat cells was characteristic of the adipose tissue of extremely obese human adults who dated their obesity from childhood (Hirsch et al. 1966) provided the starting point for an hypothesis that: (1) hypercellularity results from early nutritional experience and (2) hypercellularity results in the perpetuation of obesity. Evidence in support of either part of the hypothesis is slight (Kirtland \& Gurr, 1979). A difficulty in determining whether the number of fat cells has increased stems from the unsatisfactory methods used to 'count' fat cells. Fat cells that have not accumulated sufficient triacylglycerol are undetected but may subsequently accumulate fat and contribute to a spurious increase in the number of detected fat cells, without there being an increase in tissue DNA (Gurr \& Kirtland, 1978). Pigs proved to be useful models to study changes in cellularity since like man they have a predominantly subcutaneous distribution of fat and a similar total number of body fat cells. 'Overfeeding' either from weaning or from I year of age led to similar increases in the number of 'observable' fat cells (Gurr et al. 1977). The only effective way to determine whether an increase in the number of fat cells is due to the formation of new fat cells is to measure the incorporation of tritiated thymidine into fat cell DNA. In rats, the major part of fat cell synthesis was complete well before the final adult number of 'observable' fat cells was reached (Greenwood \& Hirsch, 1974; Kirtland \& Harris, 1980). Similarly, in pigs, the rate of incorporation of label into fat cell DNA had markedly declined when only one-tenth of the adult complement of 'observable' fat cells was present (Kirtland \& Gurr, unpublished results). These experiments are of course impossible to perform in man and one can only work by analogy from animal models. It is important to consider the time scale of adipose tissue development. Both rat and pig are born with little fat; thereafter, rapid synthesis of fat cell DNA confirms that true hyperplasia is occurring. Man is born with one-tenth of his body-weight as adipose tissue (Widdowson, 1950). A more appropriate model may be the guinea-pig whose young are born with well developed adipose tissue which incorporates label into its DNA only very slowly (Kirtland \& Gurr, 1979).

I have used these examples to illustrate the value of a comparative approach and the importance of considering the 'timing' of tissue development when assessing the importance of nutrition.

From the examples discussed in this paper it is clear that in the last 2 years, techniques for inducing obesity in laboratory animals with diets comparable to those consumed by human beings in societies where obesity is a problem have given great impetus to research. Although the use of these diets strongly implicates a role for hyperphagia in establishing a positive energy balance, there has been increasing emphasis on diet-induced thermogenesis as a primary factor in energy balance regulation and on the role of brown adipose tissue in contributing to dietinduced as well as cold-induced thermogenesis (Trayhurn et al. 1979; Rothwell \& Stock, 1979). Not all animals that are capable of displaying diet-induced thermogenesis apparently have brown adipose tissue (Gurr et al. 1980) and 
therefore the search for underlying biochemical mechanisms that can quantitatively account for changes in metabolic efficiency must look wider than at present. The distinction between primary and secondary events must be of overriding importance.

\section{REFERENCES}

Adolph, E. F. (1947). Am. $\mathscr{F}$. Physiol. 151, 110.

Ashwell, M., Meade, C. J., Medawar, P. \& Sowter, C. (1977). Proc. R. Soc. B. I95, 343.

Auffray, P., Bahy, C. \& Marcilloux, J. C. (1974). Journées Rech. Porcine en France, Paris, 6, 277.

Booth, D. A., Toates, F. M. \& Platt, S. V. (1976). In Hunger: Basic mechanisms and clinical implications. p. 127. [Novin, Wyrwicka \& Bray, editors]. New York: Raven Press.

Chaddock, T. E., Carlson, G. M. \& Hamilton, C. L. (1974). Proc. 4th Internat. Symp. Gastrointestinal motility, p. 515. Vancouver: Mitchell Press.

Cohn, C. \& Joseph, D. (1960). Metabolism, 9, 492.

Gaiton, D. J., Gilbert, C., Reckless, J. P. D. \& Kaye, J. (1974). Q. fl Med. 43, 63.

Greenwood, M. R. C. \& Hirsch, J. (1974). F. lipid Res. 15, 474.

Gurr, M. I. \& Kirtland, J. (1978). Int. F. Obesity, 2, 40r.

Gurr, M. I., Kirtland, J., Phillip, M. \& Robinson, M. P. (1977). Int. F. Obesity, I, 15 I.

Gurr, M. I., Mawson, R., Rothwell, N. J. \& Stock, M. J. (1980). F. Nutr. 110, 532.

Gurr, M. I., Rothwell, N. J. \& Stock, M. J. (1978). Proc. Nutr. Soc. 38, 6A.

Harvey, R. F., Mackie, D. B., Brown, N. J. G., Keeling, D. H. \& Davies, W. T. (1970). Lancet, i, 16.

Hervey, G. R. (1969). Nature, Lond. 223, 629.

Hirsch, J., Knittle, J. L. \& Salans, L. B. (1966). f. clin. Invest. 45, 1023.

Kirtland, J. \& Gurr, M. I. (1979). Int. f. Obesity, 3, I5.

Kirtland, J. \& Harris, P. M. (1980). Br. $\mathcal{~ Y . ~ N u t r . ~ 4 3 , ~ 3 3 . ~}$

Knittle, J. L. \& Hirsch, J. (1968). F. clin. Invest. 47, $209 \mathrm{I}$.

Leeds, A. R., Kang, S. S., Low, A. G. \& Sambrook, I. E. (1980). Proc. Nutr. Soc. 39, 44A.

Lister, D. (1980). Proc. Nutr. Soc. 39, I6r.

Lodge, G. A., Lister, D., Wood, J. D. \& Wolynetz, M. S. (1978). Anim. Prod. 27, 345.

Low, A. G. (1979). Proc. Nutr. Soc. 38, 129A.

Mayer, J. (1953). New Engl. f. Med. 249, 13.

Mayer, J. \& Thomas, D. W. (1967). Science, N.Y. 156, 328.

Miller, D. S. (1979). In Animal models of obesity, p. I3I. [M. F. W. Festing, editor]. London: Macmillan.

Miller, D. S. \& Payne, P. R. (1962). J. Nutr. 78, 255.

Rolls, B. J., Rowe, E. A. \& Turner, R. C. (I980). f. Physiol. 298, 415.

Rothwell, N. J. \& Stock, M. J. (1979). Nature, Lond. 281, 31.

Rothwell, N. J. \& Stock, M. J. (1980). Proc. Nutr. Soc. 39, 20 A.

Schemmel, R. \& Mickelsen, O. (I973). In Regulation of adipose tissue mass. p. 238. [J. Vague \& J. Boyer, editors]. Amsterdam: Excerpta Medica.

Sclafani, A. \& Springer, D. (1976). Physiol. Behav. 17, 46 I.

Standal, N., Vold, E., Trygstad, O. \& Foss, I. (1973). Anim. Prod. 16, 37.

Trayhurn, P., Thurlby, P. L., Woodward, C. J. H. \& James, W. P. T. (1979). In Animal models of obesity. p. 9r. [M. F. W. Festing, editor]. London: Macmillan.

Widdowson, E. M. (1950). Nature, Lond. 166, 626.

York, D. A. (1979). In Animal models of obesity. p. 39. [M. F. W. Festing, editor]. London: Macmillan. 